\title{
Między powieścią a lożą Edmond Jacquemin jako porte-parole rosyjskiego wolnomularza-emigranta Michaiła Osorgina
}

\author{
Dawid Trybański \\ Uniwersytet Gdański \\ Wydziat Filologiczny, Instytut Rusycystyki i Studiów Wschodnich \\ E-mail:dawid.trybanski@gmail.com \\ tutor: dr Liliana Kalita \\ Uniwersytet Gdański \\ Wydziat Filologiczny, Instytut Rusycystyki i Studiów Wschodnich
}

Stowa kluczowe: wolnomularstwo, porte-parole, Michait Osorgin, autobiografizm

W 2018 roku wybitny rosyjski masonolog Andriej Sierkow opublikował zbiór nieznanych wcześniej wystąpień lożowych ${ }^{1}$ Michaiła Osorgina (1878-1942) (Серков, 2018). Dostęp do tych dokumentów pozwolił na przeprowadzenie pogłębionej analizy twórczości pisarza-emigranta, zwłaszcza powieści Wolnomularz (Вольный каменщик, 1937). Роrównanie tekstów pozwoliło na odkrycie ważnych wątków autobiograficznych obecnych w powieści Osorgina oraz postawienie hipotezy dotyczącej ideowej warstwy tego utworu. W moim przekonaniu, przemowy lożowe Osorgina zestawione z Wolnomularzem wskazują, że Edmond Jacquemin jedna z postaci występujących w powieści jest nie tylko wyrazicielem wolnomularskich

\footnotetext{
${ }^{1}$ W dalszej części artykułu zestawione z utworem teksty przemów lożowych M.A. Osorgina cytuję za
}

poglądów autora, ale jego porte-parole, a zatem utwór ten można traktować jako formę powieści z tezą. Celem tego artykułu jest analiza powiązań ideowych między światopoglądem Osorgina, a postawą wykreowanej przez niego postaci.

Warto podkreślić, że twórczość Osorgina niejednokrotnie była przedmiotem badań. Najpełniejszą biografię literacką pisarza przedstawiła Ludmiła Polikowska w pracy Życie Michaita Osorgina (Жизнь Михаила Осоргина, 2014) (Поликовская, 2014). Działalność autora Wolnomularza analizowali również Olga Awdiejewa i wspomniany już Andriej Sierkow, których wstęp i komentarze znalazły się w wyborze prozy rosyjskiego emigranta wydanym w 1992 roku (Осоргин, 1992). Syntetyczne ujęcie motywów wolnomularskich zaproponowałem także w pracy pt. Масонские мотивы в повести «Вольный каменщик» Михаила Осоргина

А.И. Серков, М.А. Осоргин и его масонское наследие, Москва 2018. 
(Trybański, 2019). Jednak dotychczas żaden z wymienionych badaczy nie zwrócił uwagi na kluczowe znaczenie postaci Jacquemina w ideowym koncepcie tego dzieła.

Odwołując się do klasyfikacji gatunkowej zaproponowanej przez Andrieja Sierkowa, jako wolnomularskie powinno się traktować wyłącznie utwory napisane przez adeptów sztuki królewskiej (Серков, 2001: 513-514). Dlatego studium dzieła Osorgina jako tekstu masońskiego, czyli takiego, który w przestrzeni symbolicznej odwołuje się do tej tradycji ezoterycznej, wydaje się szczególnie uzasadnione.

Przypomnijmy najważniejsze wydarzenia związane z wolnomularską działalnością rosyjskiego prozaika. Za jej początek należy uznać moment przyjęcia pisarza do loży "Siewiernaja Zwiezda" (Gwiazda Północy) na Wschodzie Paryża w 1925 roku. Co prawda, masońska inicjacja autora odbyła się jedenaście lat wcześniej, we Włoszech w loży "Venti Settembre" (Серков, 1992), jednak w opinii Osorgina nie miała ona dla niego większego znaczenia, zarówno w sensie duchowym, jak i organizacyjnym. Pisarz wspominał to wydarzenie pozytywnie, ale jednocześnie podkreślał, że „за короткое время пребывания в ней (всего два года) я не получил от нее ничего ценного в масонском смысле. Это была ложа в упадке, довольно мертвая, слабо посещаемая" (Осоргин, 1998: 404). Drogę do sztuki królewskiej pisarz odkrył dopiero w loży "Siewiernaja Zwiezda”, gdy aktywnie zaangażował się w pracę i organizację rosyjskiego emigracyjnego wolnomularstwa w Paryżu.

Jak pisze Ludmiła Polikowska, w 1925 roku Osorgin ostatecznie zniechęcił się do działalności partyjnej (Поликовская, 2014: 252). Wówczas przeszedł ewolucję światopoglądową, porzucając działania społeczno-

\footnotetext{
2 Działalność polityczna była przyczyną deportowania Osorgina w 1922 roku.
}

polityczne, w które był zaangażowany jeszcze w Rosji ${ }^{2}$, na rzecz troski o sprawy związane z "duchowym obliczem" człowieka. Właśnie w Paryżu, jak zauważa badaczka, skupiła się nie tylko większość rosyjskiej emigracji, ale także rosyjskich masonów (Поликовская, 2014: 195-210, 252). Сі о роglądach demokratycznych lub liberalnych należeli najczęściej do Wielkiego Wschodu Francji, pod auspicjami którego utworzono wspomnianą lożę "Siewiernaja Zwiezda" (światła loży zapalono 26 grudnia 1924 roku). Osorgin, polecony przez Borysa Mirkina-Giecewicza $^{3}$, został do niej przyjęty 6 maja 1925 roku. Polikowska, powołując się na ustalenia Pawła Buryszkina, podkreśla, że na samym początku istnienia loża składała się głównie z emigrantów o liberalnych poglądach, którzy traktowali ją jako doskonałe miejsce do dyskusji politycznych, natomiast rytuał i symbolikę lożową najczęściej bagatelizowali (Поликовская, 2014: 253). Osorgin był przeciwny takim praktykom, co niejednokrotnie prowadziło do sporów, których echo znajdujemy w analizowanym utworze. Pisarz zdawał sobie sprawę z wielkiej wagi rytuału i symbolu, podobnie jak pierwszy Czcigodny Mistrz Loży, Nikołaj Awksjentjew, który uważał, że wolnomularstwo jest celem samym w sobie, polega na nieustannym poszukiwaniu i dążeniu do braterstwa wszystkich ludzi (Поликовская, 2014: 254).

Zdaniem Polikowskiej, Osorgin odnalazł w wolnomularstwie to, co odpowiadało jego wewnętrznemu systemowi wartości. Ideał masoński odnosił się, w jego przekonaniu, do duchowej kondycji człowieka (Поликовская, 2014: 255). Badaczka zwróciła uwagę na wyjątkową zdolność pisarza do intuicyjnego pojmowania rzeczywistości, umiejętność uchwycenia tego, co przekra-

\footnotetext{
3 Jeden z założycieli paryskiego Związku Rosyjskich Pisarzy i Dziennikarzy.
} 
czało poznanie empiryczne i rozumowe (Поликовская, 2014: 256).

Efektem doświadczeń i przemyśleń związanych z życiem na obczyźnie okazała się filozoficzna powieść Wolnomularz. W roli głównego bohatera pisarz umieścił mieszkającego w Paryżu Rosjanina - Jegora Tietiochina vel Tetekina, który z autorem i jego rodakami dzielił los emigranta. Wątek utraty ojczyzny pojawił się także w przemowach lożowych Osorgina, podobnie jak obecna w powieści krytyka rozpolitykowanych rosyjskich wolnomularzy. Chociaż wiele uwag na ten temat pada z ust Tetekina, jednak wyrazicielem najdobitniej sformułowanej krytyki jest właśnie lożowy brat Edmond Jacquemin, duchowy przewodnik Tetekina, stworzony według archetypowego obrazu Starego Mędrca. Ten klasyczny motyw inicjacyjny, którego znaczenie w procesie indywiduacji wyjaśnił Carl Gustav Jung (Sharp, 1999: 154), włączony został do powieści dzięki zastosowaniu strategii typowej dla tekstów inicjacyjnych, tj. dzięki zderzeniu dwóch przeciwstawnych postaw i systemów wartości. Pierwszą reprezentuje Lollij Pankratow - były profesor biologii, stojący na stanowisku klasycznego poznania racjonalnego, drugą - Jacquemin - doświadczony wolnomularz, Rycerz Różokrzyżowiec i Kawaler Kadosz ${ }^{4}$, uosabiający poznanie irracjonalne.

Z tymi postaciami Osorgin wiąże jeden z najważniejszych symboli wolnomularskich - budowanie Świątyni. Dla masona Świątynia jest odzwierciedleniem najwyższego ideału, do którego należy dążyć. Symbol ten wiąże się ściśle z kanoniczną dla

\footnotetext{
${ }^{4}$ W Rycie Szkockim Dawnym i Uznanym najwyższy (30) stopień wtajemniczenia, nie licząc stopni administracyjnych.

${ }^{5}$ Więcej na temat historii spekulatywnego wolnomularstwa zob. T. Cegielski, „Ordo ex chao”. Wolnomularstwo i światopoglądowe kryzysy XVII i XVIII wieku, Warszawa 1994.
}

wszystkich nurtów masonerii legendą o Mistrzu Hiramie, architekcie Świątyni Salomona (Cegielski, 1992: 90). Ponieważ ideał jest niedościgniony, praca wolnomularska, czyli przemiana świata poprzez samodoskonalenie i rozwój jednostki, nigdy nie może być uznana za zakończoną. Żeby pokazać złożoność tego procesu, ale też różne metody dążenia do ideału, pisarz przeciwstawia dwie postawy. Rozmowy z Pankratowem oraz lożowym bratem Jacqueminem stają się dla Tetekina punktem wyjścia do rozważań nad sposobami poznania i sensem życia. W tej konfrontacji światopoglądu racjonalnego i irracjonalnego ważniejszą rolę odgrywa model poznania reprezentowany przez powieściowego Rycerza Kadosz.

Jacquemin praktycznie od razu po zakończeniu agapy (uroczystego posiłku spożywanego wspólnie po zakończeniu inicjacji), wciela się w rolę nauczyciela głównego bohatera. Część ich spotkań odbywa się w gospodzie, co w sposób oczywisty odwołuje się do tradycji spekulatywnego wolnomularstwa, które narodziło się w 1717 roku w tawernie "Goose and Gridiron", gdzie powołano do życia Wielką Lożę Londynu". Rozmowy Tetekina z Jacqueminem, podobnie jak obszerne fragmenty przemów lożowych Osorgina, dotyczą złożonej symboliki masońskiej i jej znaczenia dla duchowego rozwoju człowieka.

Dzięki aktywnej imaginacji (Prokopiuk, 2008: 156-158), będącej sposobem poznania praktykowanym w różnych formacjach ezoterycznych ${ }^{6}$, główny bohater w cza-

\footnotetext{
${ }^{6}$ A. Faivre wyróżnia cztery elementy łączące różne nurty ezoteryczne. Jednym z nich jest właśnie aktywna imaginacja (Imagination and Mediations), jako sposób poznania rzeczywistości. Pozostałe trzy to: koncepcja wzajemnych powiązań różnych wymiarów mikro i makrokosmosu (Correspondences), idea żywej uniwersalnej natury (Living Nature), oraz doświadczenie głębokiej transformacji (Experience of
} 
sie tych rozmów, przenosi się do innego wymiaru rzeczywistości, znajdującego się za „синим звездным занавесом познания и посвященности" (Осоргин, 1992). Starzec objaśnia uczniowi przyczyny wejścia na tę starożytną ścieżkę Mądrości:

Мой дорогой брат, наука дает ответ на все, кроме того, на что она ответить не может. Там, где беспомощна таблица умножения, - там пытливый дух человека бредет по старым и испытанным путям великих мудрецов, по путям символического познания и мистического постижения (Осоргин, 1992).

Zawarta w cytacie myśl koresponduje z poglądami Osorgina głoszonymi podczas wystąpień w loży. Pisarz określał w nich wolnomularstwo jako „таинственный храм, мир отвлеченных символов, постижение высших духовных тайн, мистическое служение, лаборатория философского камня" (Серков, 2018: 157). W podobnym tonie Osorgin wypowiadał się wielokrotnie, co spotykało się z zarzutami braci, według których kwestionował on naukę i postęp. Doprowadziło to na przykład do sporu z bratem A:. ${ }^{7}$ W 1933 roku, gdy autor był zmuszony odpierać podobne zarzuty. Osorgin tłumaczył wówczas, że nie odrzuca osiągnięć nauki, ale jednocześnie podkreślał znaczenie postawy wychodzącej poza materialistyczną wizję świata: „масону трудно исповедовать культ непогрешимого разума, он не может оставаться ни материалистом, ни позитивистом" (Серков, 2018: 256). Pisarz odwołał się także do przykładu brata K:. ${ }^{8}$, wolnomularza cieszącego się powszechnym

Transmutation). Zob. A. Faivre, Access to Western Esotericism, tłum. C. Rhone, Albany 1994, s. 23-32.

${ }^{7}$ Najprawdopodobniej W.K. Agafonow.

${ }^{8}$ Najprawdopodobniej L.A Krolje.

${ }^{9}$ List M.A. Osorgina do M. Margulijesa z marca 1932 roku, zob. Л. Поликовская, Жизнь Михаила Осоргина..., с. 300-301. szacunkiem, który był wszakże „идеалистом чистейшей воды и любимой его темой в конце жизни было бессилие науки ответить на важные духовные запросы жизни" (Серков, 2018: 256).

Przedstawiona w powieści loża wolnomularska nieprzypadkowo borykała się z podobnymi problemami jak "Siewiernaja Zwiezda". Wewnętrzne konflikty między braćmi rodziły się $w$ niej na gruncie spraw profańskich, którymi zdaniem Osorgina zajmowano się zbyt często i zbyt chętnie ${ }^{9}$. Ten problem znalazł odzwierciedlenie w powieści, kiedy stary mason mówi o bracie "Platonie": "C'est un bon garcon, - ворчит брат Жакмен, - но слишком занят профанскими интересами! Иногда можно от них и отвлечься" (Осоргин, 1992).

$\mathrm{Na}$ problemy loży „Siewiernaja Zwiezda" zwróciła uwagę Polikowska, zauważając, że brak zainteresowania duchowym rozwojem, leżącym przecież u podstaw filozofii wolnomularskiej, stał się przyczyną stopniowo narastającego kryzysu. W 1930 roku jedno z wystąpień dotyczących pryncypiów wolnomularstwa spotkało się wręcz z prześmiewczą reakcją członków loży (Поликовская, 2014: 300).

Po tym zdarzeniu rozgoryczony Osorgin napisał list do Mistrza Pawła Pieriewierzjewa. Zdaniem pisarza, "Siewiernaja Zwiezda" zasługiwała zaledwie na miano "klubu wdowców" a nie bractwa Dzieci Wdowy ${ }^{10}$, jak z dumą nazywają siebie adepci sztuki królewskiej (Поликовская, 2014: 300).

\footnotetext{
10 Synem Wdowy nazywano w tradycji masońskiej samego Mistrza Hirama, budowniczego Świątyni Salomona. Zgodnie z tą samą tradycją, wolnomularze nazywają siebie „Dziećmi Wdowy”. Zob. J. Siewierski, Dzieci wdowy czyli opowieści masońskie, Milanówek 1992. A zatem określenie „klub wdowców” oznacza degradację prawdziwej wolnomularskiej wspólnoty do formy towarzyskiego klubu.
} 
Analogiczną krytykę loży Osorgin przedstawił także w jednej z przemów, ponownie posługując się określeniem "klub":

Мы сумели не плохо использовать идею масонства в своих целях, - но самой идее этой мы не служим и храм наш не есть подлинный Храм В.: К:. Он был и остается только прекрасным клубом. Идея Братства B.. К:. есть идея воспитывания людей, идея упрочнения в человеке человеческого, истребления в нем того, что в профанском мире людей разъединяет и восстанавливает друг против друга (Серков, 2018: 139).

Zwróćmy uwagę, że w podobnym stylu diagnozę emigracyjnego wolnomularstwa stawia powieściowy Jacquemin:

Мохом житейского порос для них кубический камень, на их чертежной доске написан только счет земных благ и барышей. Люди маленькой найденной истины, они спят с открытыми глазами, заменив уютной благорасположенностью тоску по в веках утраченному Слову. И не может быть творческого жара в сердце, сросшемся с бумажником в боковом кармане.

\section{$[\ldots]$}

Мог бы [Jacquemin], как многие другие, принять за найденное Слово маленькую пробную истину - и добавить к домашнему благополучию тот клуб порядочных людей, которым для многих стала ложа (Осоргин, 1992).

Jeszcze bardziej wzniosły ton pobrzmiewa w innej refleksji Jacquemina:

Тяжкое время переживает Братство, втянутое в заботы и раздоры мира профанов. Если теми же путями пойдет оно и дальше, - не пресечется ли традиция, связующая его с посвятительными союзами всех времен и народов? Кто должен быть на страже башни, не рыцари ли Розы и Креста? (Осоргин, 1992).

Trzeba podkreślić, że trwoga Jacquemina (a tym samym Osorgina) wynika z łamania przez lożowych braci podstawowej reguły wolnomularskiej zakazującej debat politycznych w loży:

Przeto żadne prywatne zawiści lub spory nie mogą przedostać się przez drzwi Loży, tym bardziej jakiekolwiek spory co do Religii, narodowości czy polityki państwa [...] jesteśmy [przedstawicielami] wszystkich narodów, języków, dialektów i sposobów wysławiania się. Jesteśmy też stanowczo przeciwko jakiejkolwiek polityce, ponieważ ta nigdy nie prowadziła do dobrobytu Loży, ani w przyszłości prowadzić nie będzie. Obowiązek ten był i jest ściśle utrzymywany i przestrzegany, zwłaszcza od czasu Reformacji w Brytanii (Cegielski, 2011: 409).

Słowa te pochodzą z kanonicznego dokumentu masońskiego - Konstytucji Andersona z 1723 roku. Zauważmy, że bohater powieści, podobnie jak jej autor, wyraża w ten sposób troskę o przyszłość wolnomularstwa jako formacji inicjacyjnej, odwołującej się do najwyższych wartości duchowych.

Porównanie powyższych fragmentów wskazuje na bliskie pokrewieństwo powieści i wystąpień lożowych Osorgina. Wcześniejsze chronologicznie przemowy stanowiły prawdopodobnie podstawę ideową, na której rosyjski pisarz zbudował świat przedstawiony dzieła literackiego. Dzięki tym powiązaniom Wolnomularz zyskał formę powieści filozoficznej, a nawet można uznać go za przykład powieści z tezą, w której autor głosem jednej z postaci stawia niepokojącą diagnozę rzeczywistości. Z drugiej strony, powieść można traktować jako próbę przedstawienia ideałów masonerii w formie literackiej, atrakcyjnej dla odbiorców pochodzą- 
cych z "profańskiego" świata. Opowieść Jacquemina o różokrzyżowej ścieżce wtajemniczenia, zapomnianym Słowie, budowie Świątyni i duchowej alchemii, czyli wewnętrznej przemianie adepta, w takim przypadku mogła pełnić rolę zachęty dla tych emigrantów, którzy szukali własnej ścieżki duchowego rozwoju. Być może, wydając Wolnomularza, Osorgin liczył na idealistów, którzy po przeczytaniu powieści odnajdą drogę do loży.

Zważywszy, że rosyjski pisarz w niewielkim stopniu podejmował wątki masońskie w innych utworach literackich, powieść tę można uznać za dzieło unikatowe, w którym znalazł wyraz zarówno jego wolnomularski światopogląd, jak i wieloletnie doświadczenie związane z przynależnością do loży na obczyźnie. Obok utworów takich autorów jak Lew Gojer, Siergiej Makowskij czy Mark Ałdanow, powieść Michaiła Osorgina wpisuje się w bogatą masońską tradycję literatury rosyjskiej XX wieku (Серков, 2001: 513-514).

\section{Literatura:}

Cegielski T., 1992. Sekrety masonów. Pierwszy stopień wtajemniczenia, Warszawa.

Cegielski T., 1994. "Ordo ex chao". Wolnomularstwo i światopogladowe kryzysy XVII i XVIII wieku, Warszawa.

Cegielski T., 2011. Księga Konstytucji 1723 roku i początki wolnomularstwa spekulatywnego w Anglii: geneza, fundamenty, komentarze, tłum. "Konstytucji Wolnych Mularzy" Jamesa Andersona z 1723 roku T. Cegielski, Warszawa.

Eliade M., 2009. Obrazy i symbole, tłum. M. i P. Rodakowie, Warszawa.

Faivre A., 1994. Access to Western Esotericism, tłum. C. Rhone, Albany.

Fijałkowska-Janiak I., 2006. Literackie wizje wolnomularskich przestrzeni, [w:] Motywy ezoteryczne w kulturze rosyjskiej poczq̨tku XX wieku (Światło i ciemność, t. 2), red. E. Biernat, M. Rzeczycka, Gdańsk, s. 152184.

Mainguy I., 2020. Symbolika masońska trzeciego tysiąclecia, tłum. L. Skurczyński, A. Drzymała, K. Milewska, M. Zawadzka, Warszawa.

Prokopiuk J., 2008. Mój Jung, Katowice.

Sharp D., 1999. Leksykon pojęć i idei C.G. Junga, tłum. J Prokopiuk, Wrocław.

Siewierski J., 1992. Dzieci wdowy czyli opowieści masońskie, Milanówek.

Trybański D., 2019. Масонские мотивы в повести "Вольный каменщик" Михаила Осоргина (Motywy masońskie w opowieści "Wolnomularz" Michaita Osorgina). Praca dyplomowa obroniona w Instytucie Rusycystyki i Studiów Wschodnich, Uniwersytet Gdański, Archiwum Uniwersytetu Gdańskiego.

Осоргин М.А., 1992. Вольный каменщик: Повесть. Рассказы, предисл. О.Ю. Авдеевой и А.И. Серкова, подготовка текста О.Ю. Авдеевой, комм. А.И. Серкова, Москва, [online] https://royallib.com/read/osorgin_mihail/volniy_kamenshchik.html\#0 [Dostęp: 02.03.2021]

Осоргин М.А., 1998. Исповедь мастера, [w:] Новиков В.И., Масонство и русская культура, Москва.

Серков А.И., М.А. 2018. Осоргин и его масонское наследие, Москва.

Серков А.И., 2001. Масонство, [w:] Литературная энциклопедия терминов и понятий, Гл. ред. и сост. А.Н. Николюкин, Москва, s. 513-514.

Поликовская Л.В., 2014. Жизнь Михаила Осоргина, Санкт-Петербург.

Notka o autorze: Dawid Trybański - student drugiego roku studiów magisterskich filologii rosyjskiej na Uniwersytecie Gdańskim. Główne zainteresowania badawcze: historia wolnomularstwa (zwłaszcza rosyjskiej masonerii emigracyjnej) oraz rosyjska literatura ezoteryczna 